\title{
LATIN AMERICAN COOPERATION TO REDUCE POVERTY AND PROTECT HUMAN RIGHTS ${ }^{1}$
}

\section{Valerio de Oliveira Mazzuoli*}

Como citar: MAZZUOLI, Valerio de Oliveira. Latin American Cooperation to reduce poverty and protect human rights. Revista do Instituto de Direito Constitucional e Cidadania, Londrina, v. 3, n. 2, p. 55-63, jul/dez. 2018.

https://doi.org/10.48159/revistadoidcc.v3n2.mazzuoli

Abstract: This paper analyzes the challenges to eradicate poverty and extreme poverty in Latin America. Moreover, it seeks to understand the recommendations from the Inter-American Commission on Human Rights on this topic. Accordingly, this paper focuses on the United Nations and the Inter-American human rights systems to combat poverty (the legal instruments and monitoring bodies) and the goals states need to follow to better protect economic, social and cultural rights, and to provide an effective access to justice in the Americas.

* Associate Professor of the Faculty of Law of the Federal University of Mato Grosso, Brazil. PhD summa cum laude in International Law (Federal University of Rio Grande do Sul, Brazil). Master of Laws (São Paulo State University, Brazil). Former postdoctoral researcher at the Lisbon University, Portugal. Professor of the Masters Program in Human Rights at the University of Itauna, Brazil. Member of the Brazilian Society of International Law and the Brazilian Association of Democratic Constitutionalists. Attorney at Law.
Keywords: Poverty. Extreme poverty. Economic. Social and cultural rights. Access to justice. 


\section{INTRODUCTION}

Poverty reduction and extreme poverty reduction area constant source of concern in the Americas, especially in Latin America. Although this issue is complex and with practical challenges, there are measures created to tackle the poverty and extreme poverty problems. The Inter-American Commission on Human Rights (IACHR) has since 2001 monitored the poverty issue in the hemisphere asserting it constitutes a violation of all human rights, that is, a breach of civil, political, economic, social and cultural rights. ${ }^{2}$

Indeed, poverty, and especially the extreme poverty that affects a large proportionof the Latin American population leads to a violation of a number of human rights enshrined in international treaties addressing both civil and political rights, and economic, social and cultural rights. Moreover, going beyond being a factor for state responsibility at the international plane, this poverty situation demonstrates the failure of these states in making sure that all of their population can have access to basic human rights.

In the American continent, especially in Latin America, there are high levels of poverty rates in various countries including in Haiti, Honduras, Nicaragua, Bolivia, Guatemala, Paraguay, El Salvador, Jamaica and Venezuela. These rates show that a whole group of people is invisible, which impedes the protection of their human rights. Following this argument, the Inter-American Commission on Human Rights in its country report on Paraguay asserted that "the torture of a single individual rightly raises public outrage... yet the deaths of more than 30,000 children every day from mainly preventable causes go unnoticed". ${ }^{3}$ Accordingly, the first task is to make visible the poverty issue in Latin America in order to establish measures that can eradicate it.

Currently, estimations point that there are 186 million people living in poverty in Latin America, which comprises $30.7 \%$ of the population; and there are 61 million people in extreme poverty, which comprises $10 \%$ of the Latin American population. ${ }^{4}$ Even with the decrease on the number of people living in poverty in the past years, the current situation in Latin American is still chaotic requiring urgent measures to ensure economic increase and poverty reduction.

Accordingly, the focus is in understanding the global and Inter-American systems that address poverty and the challenges to implement measures and policies to combat poverty in Latin America.

\section{I - THE UNITED NATIONS AND THE INTER-AMERICAN HUMAN RIGHTS SYSTEM AGAINST POVERTY}

It seems obvious that human rights norms from both the global system (the United Nations) and the Inter-American system place on states the duty to eradicate poverty in their territory and ensure standard of living with dignity to all their citizens. It is, nonetheless, important to examine in more detail the mechanisms from the United Nations designed to combat poverty and the work

2 IACHR, Third Report on the Situation of Human Rights in Paraguay, 2001, § 5.

3 IACHR, Third Report on the Situation of Human Rights in Paraguay, 2001, Chap. V, $\S 10$.

4 CEPAL, Social Panorama of Latin America, New York, 2018. 
of the Inter-American bodies (the Organization of American States - OAS, and the Inter-American Commission on Human Rights). ${ }^{5}$

\section{A - United Nations mechanisms against poverty and economic, social and cultural rights}

Within the United Nations (UN) system, the struggle against poverty is highlighted in the preambles of both the International Covenant on Civil and Political Rights (ICCPR) and theInternational Covenant on Social, Economic and Cultural Rights (ICSECR), which establish that" in accordance with the Universal Declaration of Human Rights, the ideal of free human beings enjoying freedom from fear and want can only be achieved if conditions are created whereby everyone may enjoy his economic, social and cultural rights, as well as his civil and political rights". The Portuguese translation of this preamble goes even further explicitly mentioning misery as the translation for "free from fear and want" is "liberto do medo e da miséria", which literally means "free from fear and misery". Accordingly, both these treaties from 1966 set the theoretical groundwork for the United Nations mission to seek to eradicate poverty across the globe.

Similarly, the Vienna Declaration and Program for Action from 1993 establishes in paragraph 14 that the "existence of widespread extreme poverty inhibits the full and effective enjoyment of human rights" and"its immediate alleviation and eventual elimination must remain a high priority for the international community". The same instrument, in paragraph 25 , spells out that "extreme poverty and social exclusion constitute a violation of human dignity and that urgent steps are necessary to achieve better knowledge of extreme poverty and its causes, including those related to the problem of development, in order to promote the human rights of the poorest, and to put an end to extreme poverty and social exclusion and to promote the enjoyment of the fruits of social progress". To that end, the same paragraph affirms that states need "to foster participation by the poorest people in the decision-making process by the community in which they live, the promotion of human rights and efforts to combat extreme poverty".

Based on this line of thought, the Human Rights Committee - the body that oversees the compliance with the International Covenant on Civil and Political Rights - and the United Nations Human Rights Council agree that states must make every possible effort to eradicate poverty and extreme poverty in the world assuring that people have minimum levels of sanitation and food. ${ }^{6}$

In July of 2012, in order to advance the protection of the human person against poverty, the United Nations adopted the Guiding Principles on Extreme Poverty and Human Rights written by the United Nations' Special Rapporteur based on consultations with states and their stakeholders since the beginning of the document's drafting procedure in 2001. These Guiding Principlesare crucial for the elaboration and application of public policies intended to eradicate poverty. Moreover, these principles work as general guidelines for protection, respect and concretization of

5 IACHR, Preliminary report on poverty, extreme poverty, and human rights in the Americas, 2016, § 18-21. 6 UN, Committee on Economic, Social and Cultural Rights, General Observationn ${ }^{\circ} 3, \S 10$; andUN, Human Rights Council, The Guiding Principles on Extreme Poverty and Human Rights, Doc. A/HRC/Res./21/11. 
the human rights of those individuals living in poverty. ${ }^{7}$ Furthermore, these Guiding Principlesare universal and every state should comply with them regardless of the state's economic development level. $^{8}$

\section{B - The work of the Organization of American States (OAS) and the Inter-American Commission on Human Rights (IACHR) combating poverty}

On pair with the United Nations, the Inter-American human rights system - part of the Organization of American states - also took measures for poverty reduction and extreme poverty reduction in the Americas. There are, however, major difficulties in addressing poverty in this hemisphere. There are more obstacles in combating poverty in developing states compared to developed nations, which have better sanitation and access to food. It is, nonetheless, important to analyze the efforts from the Organization of American States (OAS) in seeking to eradicate poverty in the Americas. In 2015, the General Assembly of the Organization of American States (in Washington, D.C.) approved the Plan of Action of the Social Charter of the Americas(Plan of Action). This document addresses issues concerning work, health, food, education, housing, and basic public services. Through this Plan of Action, the member statesof the OAS make a commitment to eradicate poverty and hunger in their territory protecting all peoples from social exclusion and inequality. ${ }^{9}$

Detailing issues that were later addressed by thePlan of Action, the Inter-American Democratic Charter (from September 11, 2001) reaffirms, in its preamble, "the fight against poverty, and especially theelimination of extreme poverty, is essential to the promotionand consolidation of democracy and constitutes a commonand shared responsibility of the American states". Moreover, section III of the Democratic Charter - entitled Democracy, Integral Development, and Combating Poverty - spells out that "the OAS member states are committed to adopting andimplementing all those actions required to generate productiveemployment, reduce poverty, and eradicate extreme poverty,taking into account the different economic realities andconditions of the countries of the Hemisphere" (article 12). Moreover, article 12 adds that [t]his sharedcommitment regarding the problems associated withdevelopment and poverty also underscores the importanceof maintaining macroeconomic equilibria and the obligationto strengthen social cohesion and democracy".Finally, article 16 of the Democratic Charter provides that" [e]ducation is key to strengthening democratic institutions,promoting the development of human potential, andalleviating poverty and fostering greater understandingamong our peoples". Moreover, article 16 acknowledges that to "achieve these ends, it is essential thata quality education be available to all, including girls andwomen, rural inhabitants, and minorities".

The greatest challenge in the Americas is to assure that all these policies areeffectively

7 UN, Human Rights Council, The Guiding Principles on Extreme Poverty and Human Rights, Doc. A/HRC/ Res./21/39, § 11 .

8 UN, Human Rights Council, The Guiding Principles on Extreme Poverty and Human Rights, Doc. A/HRC/ Res./21/39, § 12 .

9 OAS, Plan of Action of the Social Charter of the Americas, Res. 2878 (XLV-O/15). 
implemented in order to eliminate poverty. The American continent still faces high levels of inequality and poverty, and low access to food and sanitation. Accordingly, recommendations from the Inter-American Commission on Human Rights are keyaspects in order to better address issues concerning poverty for all member states of the OAS.

\section{II - CHALLENGES TO ANEFFECTIVE COMBAT AGAINST POVERTY IN LATIN AMERICA}

According to the United Nations Economic Commission for Latin America and the Caribbean (ECLAC), levels of poverty and extreme poverty have increased in Latin America between the years of 2015 and 2016 after more than a decade of constant decreasing rates in most states. Based on statistical data from 2014, $28.5 \%$ of the region's population lives in poverty (168 million people). This number increased to $29.8 \%$ in 2015 (178 million) and to $30.7 \%$ in 2016 (186 million). The extreme poverty rates went from $8.2 \%$ in 2014 (48 million people) to $10 \%$ in 2016 (61 million people). ${ }^{10}$

The Inter-American Commission on Human Rights has put forward the view that poverty is a multidimensional phenomenon that not only includes a material lack, that is, not having the means to have goods and services, but also a situation of social exclusion and marginalization that is characterized by multiples and interconnected breaches of civil, political, economic, social and cultural rights. ${ }^{11}$ This view highlights the challenges to implement measures to combat poverty in Latin America, which requires a special attention from states. Moreover, the America Convention on Human Rights - the main human rights treaty of the OAS - places further legal obligations on its state parties to eradicate poverty in the Americas stressing out in its preamble that states need to establish the conditions whereby everyone may enjoy his economic, social, and cultural rights, as well as his civil and political rights.

Accordingly, there are two main challenges in the Inter-American system concerning the combat of poverty. First, there is a need to secure the protection of economic, social and cultural rights. Secondly, it is necessary to have an effective system that assures the access to justice.

\section{A - Challenges to an effective protection of economic, social and cultural rights}

Within the Inter-American human rights system, the Additional Protocol in the area of Economic, Social and Cultural Rights, also known as the "Protocol of San Salvador" (from 1988) complements the American Convention on Human Rights (from 1969) mirroring the ICCPR and the ICESCR of the United Nations. The "Protocol of San Salvador", in its preamble, refers to the Universal Declaration of Human Rights and the American Convention asserting that "free human beings enjoying freedom from fear and want can only be achieved if conditions are created whereby everyone may enjoy his economic, social and cultural rights as well as his civil and political 10 CEPAL, Social Panorama of Latin America, New York, 2018.

11 IACHR, Preliminary report on poverty, extreme poverty, and human rights in the Americas, $2016, \S 70$. 
rights". Here again, the preamble stresses the importance of an interconnected and complementary view of human rights and informsthat individuals should have access to basic needs, that is should be "free from fear and want", which arguably addresses issues concerning poverty and extreme poverty. This is link is especially clear in the Portuguese version that translates "fear from fear and want" as "isento de temor e da miséria" (literally meaning "free from fear and misery"). Moreover, article 10, paragraph 2 of this Protocol spells out that "in order to ensure the exercise of the right to health, the States Parties agree to recognize health as a public good" and should adopt measures such as those addressing the "needs of the highest risk groups and those whose poverty makes them the most vulnerable".

Accordingly, of all the challenges to implement economic, social and cultural rights of people in poverty, it is possible to mention three main ones. First, there is a need to assure equal treatment and non-discrimination to all peoples in poverty. Second, social exclusion and violence are issues that people in poverty face and need to be properly addressed by authorities and society at large. Finally, there is a need to assure the right to a life with dignity, which can also be achieved with public policies addressing the root causes of poverty. ${ }^{12}$ States havethe duty to address the social needs of people in poverty by designing policies that, among other objectives, seek to provide better working conditions, establish a more efficient and socially conscious tax and welfare systems, and setlivable minimum wage.

The Inter-American Court of Human Rights, a judicial body of the OAS designed to apply the American Convention, can also hear cases concerning economic, social and cultural rights. In the case of Lagos del Campo vs Peru (from 2017), the Inter-American Court dealt with a labor law issue concerning a worker who was fired after criticizing his company. In this case, the Inter-American Court recognized, for the first time, the direct applicability of economic, social and cultural rights (through article 26 of the American Convention) deciding that the concerned state breached the right to job stability. ${ }^{13}$

The decision of Lagos del Campocrystalized the view that state parties to the American Convention have to comply with economic, social and cultural rights established by the Protocol of San Salvador. In other words, although the Inter-American Court oversees the application of the American Convention, which mainly establishescivil and political rights, this adjudicative body can also hear cases concerning economic, social and cultural rights. Consequently, parties to the American Convention on Human Rights can be held liable for violating this set of rights before adjudicative bodies of the OAS.

The first time the Inter-American Court of Human Rights established that states can be liable for human rights violations in the Americas was in 29 of July of 1988 when this Court held that any

12 IACHR, Preliminary report on poverty, extreme poverty, and Human rights in the Americas, 2016, §§ 91142.

13 Int-Am. Court H.R., Lagos del Campo Case Vs. Peru, 31 August 2017, case n. 340; and Int-Am. Court H.R., San Miguel Sosa Case and Others Vs. Venezuela, 8 February 2018,case n. 348. 
violation of rights enshrined in the American Convention "carried out by anact of public authority or by persons who use their position of authority is imputable to the State" and due to the "the lack of due diligence to prevent the violation or to respond to it as required by the Convention". ${ }^{14}$

Accordingly, states should take the necessary measures to strengthen labor and welfare systems, especially in times of economic unrest or recession, to avoid any increase of poverty rates. It is worrisome to note that ECLAC's report from 2017 highlights that poverty and extreme poverty rates are higher amongst children, teenagers, youngsters, women and people who live in rural areas. States also need to pay a closer look at welfare benefits and the pension system taking into account that studies show that in 2040 there will be more people over 60 than between the ages of 0 and 14, and that there will be an increase of 20 million people who will be 80 or older by that same year. ${ }^{15}$

It is, therefore, crucial to envisage a system of international cooperation to provide assistance to the poorer and more unequal parts of the world. States, especially the wealthiest ones, have a common obligation to eradicate world poverty.

\section{B - Challenges to establish an effective legal system that assures access to justice}

A common challenge to many Latin American states is the need of an effective legal system that guarantees access to justice to all is citizens. This is particularly important for people in poverty, as they are marginalized members of society. This marginalization is not only financial but also legal as they have little access to courts and state bodies.

In line with this understanding, the Inter-American Commission on Human Rights highlighted that certain individuals in poverty face discrimination and social exclusion, which harm citizen participation, access to justice, and the effective enjoyment of human rights. ${ }^{16}$ Recognizing the importance of the access to justice for the eradication of poverty, the Inter-American Commission on Human Rights stresses that breaching economic, social and cultural rights also impacts civil and political rights. ${ }^{17}$

Acknowledging the importance of the access to justice, the constitution of many states in the Americas expressly refers to it as a human right. In the Brazilian Constitution, for example, the access to justice is in article 5, section 35, when it provides that "the law shall not exclude any injury or threat to a right from theconsideration of the Judicial Power". However, although the access to justice is spelled out in the constitutions of many states in the Americas, it is still far from being effectively applicable, especially concerning the access to justice for people in poverty or in extreme poverty. At the international level, a number of international treaties such as the American Convention (article 8,1) crystalize the access to justice is a human right. Accordingly, people in poverty or extreme poverty, especially women and afro-descendants, face further marginalization 14 Int-Am. Court H.R., Velásquez Rodríguez Case Vs. Honduras, 29 July 1988, case n. 4, § 172.

15 CEPAL, Social Panorama of Latin America, 2018.

16 IACHR, Preliminary report on poverty, extreme poverty, and human rights in the Americas, 2016 , $\$ \$ 241$.

17 Idem. 
and discrimination due to their lack of resources to access courts and the legal system in general.

Acknowledging this reality, the Inter-American Court of Human Rights has decided that states must provide legal aid services to people without financial means in order to guarantee an effective access to justice. The Court's reasoning is that article 1 (1) of the American Convention prohibits any state-based discrimination including economic discrimination. Accordingly, it would constitute a discriminatory treatment if the lack of economic resources to pay, for example, legal fees or to hire a lawyer hinders someone's access to justice, as groups of people would not be envisaged as equal before the law. ${ }^{18}$

The greatest challenge, therefore, for the application of economic, social and cultural rights for people in poverty or extreme poverty is an effective access to justice provided by the state. This access to justice cannot only address financial aspects but also institutional ones such as a preeminent public defense system for the protection of individual and collective rights. The Inter-American Commission, thus, recommended that a "comprehensive, coordinated state policy be designed and backed up with the necessary public resources to ensure that persons living in poverty and extreme povertyhave access to adequate judicial protection". ${ }^{19}$

\section{CONCLUSION}

There are multiple challenges to eradicate poverty in the Americas, especially in the developing nations of this hemisphere. Although there are a number of international norms designed to protect economic, social and cultural rights and there are case laws from the Inter-American Court of Human Rights asserting its jurisdiction when it comes to this group of human rights, there is still difficulties, in practice, to eradicate poverty and extreme poverty in the Americas.

Constitutions from Latin American states (such as Brazil, for example) provide the access to justice as a basic human right. The same rule is also part of a number of human rights treaties in the Americas (such as the American Convention on Human Rights). However, poverty and extreme poverty couple with discrimination and lack of state support impair an effective access to justice in Latin American countries. Accordingly, there is a need to demand state policies that can increase the minimum wage, decrease cases of discrimination and establish a more effective system of public advocacy.

International cooperation whereby states can assist each other provides a path of development that can leadto a better world for everyone with equal possibilities for all to move away from poverty. To that end, states should join efforts to combat discrimination and marginalization of all individuals in poverty. Moreover, states need to comply with the international commitments they have agreed upon. Although it is not easy to end poverty, especially in developing areas such as Latin America and Africa, it is possible and there is still hope.

\section{FERENCES"}


Como citar: MAZZUOLI, Valerio de Oliveira. Latin American Cooperation to reduce poverty and protect human rights. Revista do Instituto de Direito Constitucional e Cidadania, Londrina, v. 3, n. 2, p. 55-63, jul/dez. 2018. 
* Doutor e Mestre em Direito Constitucional pela Faculdade de Direito da UFMG. Professor de Teoria do Estado, Direito Constitucional, Direito Internacional, Direito da União Europeia e TGDP nos cursos de Doutorado, Mestrado e Bacharelado da Faculdade Mineira de Direito da PUC/MG. Membro do Colegiado de Coordenação Didática da Pós-Graduação em Direito da PUC/MG. Presidente do Centro de Estudos de Direito Público. Presidente da Comissão de Estudos Constitucionais da $\mathrm{OAB} / \mathrm{MG}$. Conselheiro Seccional da OAB/MG.E-mail:mlquintao@, yahoo.com.br

\section{MEIO AMBIENTE E A INEFICIÊNCIA DOS PODERES PÚBLICOS BRASILEIROS $^{1}$}

\section{ENVIRONMENT AND The INEFFICIENCY Of The BRAZILIAN STATE}

\section{Mário Lúcio Quintão Soares*}

Como citar: SOARES, Mário Lúcio Quintão. Meio ambiente e a ineficiência dos poderes públicos brasileiros. Revista do Instituto de Direito Constitucional e Cidadania, Londrina, v. 3, n. 2, p. 64-78, jul/dez. 2018.

Resumo: Laudo técnico do IBAMA(Instituto Brasileiro do Meio Ambiente e dos Recursos Naturais Renováveis), publicado em dezembro de 2015, relatou a morte de trabalhadores da Samarco e de moradores das comunidades afetadas, o desalojamento de pessoas, a devastação de localidades, a destruição de 1.469 hectares de vegetação, incluindo Áreas de Preservação Permanente, a mortandade de biodiversidade aquática e fauna terrestre, a perda e na fragmentação de habitats, a interrupção da pesca por tempo indeterminado, a interrupção do turismo, a alteração dos padrões de qualidade da água doce, salobra e salgada, a interrupção do abastecimento de água e a dificuldade de geração de energia elétrica pelas hidrelétricas atingidas. $\mathrm{O}$ presente texto apresenta a problemática acima descrita, contextualizando-a segundo o Direito brasileiro e também de acordo com o Direito Internacional Público. Aqui é denunciada a ineficiência dos Executivos da União e de Minas Gerais, os Judiciários da União e de Minas Gerais, e os Ministérios Públicos da União e de Minas Gerais.

Palavras-chave: Desastre ecológico na cidade de Mariana. Direitos humanos. Responsabilidade da poluidora.

Abstract: A technical report from IBAMA(Brazilian Institute for the Environment and Renewable Natural Resources), published in December 2015, reported the deaths of Samarco workers and 1 Este artigo é dedicado ao Professor Doutor Zulmar Fachin. 